\title{
Structural Equation Modeling (SEM) untuk Mengukur Pengaruh Pelayanan, Harga, dan Keselamatan terhadap Tingkat Kepuasan Pengguna Jasa Angkutan Umum Selama Pandemi Covid-19 di Kota Ambon
}

\author{
Zakheus Putlely $^{1}$, Yopi Andry Lesnussa ${ }^{2}$, Abraham Z. Wattimena ${ }^{3}$, Muhammad Yahya Matdoan ${ }^{4}$ \\ ${ }_{1,2,3,4}$ Universitas Pattimura \\ putlelyzakheus@gmail.com
}

\begin{abstract}
Structural Equation Modeling (SEM) is a statistical analysis technique used to build and test statistical models in the form of causal models. Large-Scale Social Restrictions (PSBB) are government policies to break the chain of spreading the corona virus (Covid-19). This policy certainly has an impact on drivers of public transport services. This research shows that the passengers are very satisfied with the travel safety factor. Meanwhile, service factors and passenger public transport fares are in the satisfied category. Furthermore, the variable service quality (MP), the price of public transportation $(\mathrm{H})$, and passenger safety (KP) have an influence on passenger satisfaction. Because the $t$-value is greater than 1.96 (for the real level of $5 \%$ ). The influence of service quality, price and safety variables on passenger satisfaction is $78.1 \%$, the remaining $21.9 \%$ is influenced by other variables outside the research.
\end{abstract}

Keywords: covid-19, structural equation modeling, satisfaction.

\section{Pendahuluan}

Pada akhir tahun 2019 dunia dikejutkan dengan wabah virus corona (Covid-19) yang menginfeksi hampir seluruh negara di dunia [1]. Sejak Januari 2020 WHO telah menyatakan darurat global terkait virus ini. Langkah strategis telah dilakukan oleh pemerintah untuk dapat menyelesaikan kasus luar biasa ini salah satunya dengan menyosialisasikan gerakan social distancing [2]. Konsep ini menjelaskan bahwa untuk dapat mengurangi bahkan memutus mata rantai infeksi Covid-19, seseorang harus menjaga jarak dengan manusia lainnya minimal 2 meter, tidak melakukan kontak langsung dengan orang lain, dan menghindari pertemuan massal. Tetapi banyak masyarakat yang tidak menyikapi hal ini dengan baik.

Provinsi Maluku merupakan wilayah dalam Negara Kesatuan Republik Indonesia (NKRI), tentu tidak terlepas dari masalah penyebaran Covid-19. Hal ini berdampak pada aktivitas masyarakat pada umumnya. Sejak diberlakukannya darurat bencana oleh pemerintah pusat, maka pemerintah daerah melakukan hal yang sama. Pembatasan Sosial Berskala Besar (PSBB) merupakan kebijakan Pemerintah untuk memutuskan mata rantai penyebaran virus corona (Covid-19). Diberlakukannya PSBB, hampir semua aktivitas dilakukan di rumah [3]. Kebijakan ini tentu berdampak pada perekonomian masyarakat, khususnya masyarakat yang berprofesi sebagai pengemudi jasa angkutan umum. Hal ini 
disebabkan karena pemerintah memberlakukan kebijakan bahwa setiap mobil angkutan umum maksimal mengangkut penumpang sebanyak 5 orang dalam sekali jalan, guna memutus mata rantai Covid-19 [4]. Namun dalam pelaksanaanya masih terdapat angkutan umum yang mengangkut lebih dari 5 orang dan bahkan masih terdapat penumpang yang tidak menggunakan masker. Selain itu, terdapat angkutan umum yang menaikkan harga transportasi disebabkan karena kapasitas penumpang yang hanya maksimal 5 orang dalam sekali jalan dan jika tidak dinaikkan maka sopir angkutan umum akan memperoleh kerugian. Selain itu, masih banyak angkutan umum yang tidak memberikan pelayanan dengan baik seperti menyediakan antiseptik atau desinfektan. Hal ini akan berdampak pada keselamatan penumpang terhadap wabah Covid-19 dalam angkutan umum.

Structural Equation Modeling (SEM) merupakan salah satu teknik analisis statistik yang digunakan untuk membangun dan menguji model statistik dalam bentuk model-model sebab akibat [5]. Analisis SEM menggabungkan analisis regresi, faktor, dan jalur sehingga secara simultan menghitung hubungan yang terjadi antara variabel laten, mengukur nilai loading dari indikator-indikator variabel laten, dan menghitung model jalur dari variabel-variabel laten tersebut [6]. Pada dasarnya, SEM adalah salah satu teknik multivariat yang akan menunjukkan bagaimana cara merepresentasikan suatu seri atau deret hubungan kausal (causal relationship) dalam suatu diagram jalur (path diagram).

\section{Landasan Teori}

\subsection{Sejarah Structural Equation Modeling (SEM) dan Pengertian}

SEM adalah suatu teknik statistik yang mampu menganalisis pola hubungan antara konstruk laten dan indikatornya, konstruk laten yang satu dengan lainnya, serta kesalahan pengukuran secara langsung. SEM memungkinkan dilakukannya analisis diantara beberapa variabel dependen dan independen secara langsung [7]. Alasan yang mendasari digunakannya SEM yaitu

1. SEM mempunyai kemampuan untuk mengestimasi hubungan antar variabel yang bersifat multiple relationship. Hubungan ini dibentuk dalam model struktural (hubungan antara konstruk dependen dan independen).

2. SEM mempunyai kemampuan untuk menggambarkan pola hubungan antara konstruk laten dan variabel manifes atau variabel indikator.

\subsection{Persamaan Matematis dalam SEM}

1. Persamaan model struktural 


$$
\begin{aligned}
& \eta_{1}=\gamma_{11} \xi_{1}+\zeta_{1} \\
& \eta_{2}=\gamma_{22} \xi_{2}+\zeta_{2} \\
& \eta_{3}=\beta_{31} \eta_{1}+\beta_{32} \eta_{2}+\zeta_{3}
\end{aligned}
$$

2. Persamaan model pengukuran variabel eksogen

$$
\begin{aligned}
& X_{1}=\lambda_{11} \xi_{1}+\delta_{1} \\
& X_{2}=\lambda_{21} \xi_{1}+\delta_{2} \\
& X_{3}=\lambda_{12} \xi_{2}+\delta_{3}
\end{aligned}
$$

3. Persamaan model pengukuran variabel endogen

$Y_{1}=\lambda_{13} \eta_{1}+\varepsilon_{1}$

$Y_{2}=\lambda_{23} \eta_{1}+\varepsilon_{2}$

$Y_{3}=\lambda_{33} \eta_{1}+\varepsilon_{3}$

\section{Keterangan:}

$\eta$ : variabel laten endogen

$\xi$ : variabel laten eksogen

$\gamma$ : koefisien pengaruh variabel eksogen terhadap variabel endogen

$\beta$ : koefisien pengaruh variabel endogen terhadap variabel endogen

$\delta$ : galat pengukuran pada variabel manifest untuk variabel laten eksogen

$\varepsilon$ : galat pengukuran pada variabel manifest untuk variabel laten endogen

$\lambda:$ loading faktor

\subsection{Proses Analisis SEM}

Menurut [7] terdapat tujuh langkah yang harus dilakukan apabila menggunakan SEM yaitu

1. Pengembangan Model Teoritis

Pada langkah pengembangan model teoritis, hal yang harus dilakukan adalah melakukan serangkaian eksplorasi ilmiah melalui telaah pustaka guna mendapatkan justifikasi atas model teoritis yang akan dikembangkan.

2. Pengembangan Diagram Alur

Pada langkah kedua ini, model teoritis yang telah dibangun pada tahap pertama akan digambarkan dalam sebuah diagram alur yang akan mempermudah untuk melihat hubungan kausalitas yang ingin diuji. Pada diagram alur, hubungan antar konstruk akan dinyatakan melalui anak panah. Anak panah yang lurus menunjukkan sebuah hubungan kausal yang langsung antara satu konstruk lainnya [8]. Sedangkan garis-garis lengkung antar konstruk dengan anak panah 
pada setiap ujungnya menunjukkan korelasi antara konstruk. Konstruk yang dibangun dalam diagram alur dapat dibedakan dalam dua kelompok, yaitu [5]

a) Konstruk eksogen (exogenous constructs), yang dikenal juga sebagai source variables atau independent variables yang akan diprediksi oleh variabel yang lain dalam model. Konstruk eksogen adalah konstruk yang dituju oleh garis dengan satu ujung panah.

b) Konstruk endogen (endogen constructs), merupakan faktor-faktor yang diprediksi oleh satu atau beberapa konstruk. Konstruk endogen dapat memprediksi satu atau beberapa konstruk endogen lainnya, tetapi konstruk eksogen hanya dapat berhubungan kausal dengan konstruk endogen.

3. Konversi diagram alur ke dalam persamaan-persamaan yang diperoleh dari diagram alur yang dikonversi terdiri dari :

a) Persamaan struktural (structural equation) yang dirumuskan untuk menyatakan hubungan kausalitas antar berbagai konstruk.

Variabel endogen $=$ variabel eksogen + variabel endogen + error

b) Persamaan spesifikasi model pengukuran (measurement model), dimana harus ditentukan variabel yang mengukur konstruk dan menentukan serangkaian matriks yang menunjukkan korelasi antar konstruk atau variabel.

4. Memilih matriks input dan estimasi model

SEM menggunakan input data yang hanya menggunakan matriks varians/kovarians atau matriks korelasi untuk keseluruhan estimasi yang dilakukan. Matriks kovarian digunakan karena SEM memiliki keunggulan dalam menyajikan perbandingan yang valid antara populasi yang berbeda atau sampel yang berbeda, yang tidak dapat disajikan oleh korelasi.

5. Kemungkinan munculnya masalah identifikasi

Masalah identifikasinya adalah masalah mengenai ketidakmampuan dari model yang dikembangkan untuk menghasilkan estimasi yang unik. Apabila setiap kali estimasi dilakukan muncul masalah identifikasi, maka sebaiknya model dipertimbangkan ulang dengan mengembangkan lebih banyak konstruk.

6. Evaluasi kriteria goodness of fit

Pada tahap ini dilakukan pengujian terhadap kesesuaian model melalui telaah terhadap berbagai kriteria goodness of fit.

7. Interpretasi dan modifikasi model 
Tahap terakhir ini adalah menginterpretasikan model dan memodifikasi model bagi model-model yang tidak memenuhi syarat pengujian yang dilakukan.

\section{Hasil dan Pembahasan}

\subsection{Gambaran Umum Variabel Penelitian}

Gambaran umum variabel penelitian dapat dirincikan sebagai berikut

\section{a) Variabel Kepuasan Penumpang ( $Y$ )}

Analisa data variabel kepuasan penumpang mempunyai 3 butir pertanyaan pada instrumen serta memiliki 5 pilihan yaitu (sangat puas, puas, cukup, tidak puas, dan sangat tidak puas), sehingga skor butir dapat ditentukan sebagai berikut :

Skor tertinggi $5 \times 3=15$

Skor terendah $1 \times 3=3$

Range $=12$

Adapun secara rinci deskripsi kepuasan penumpang berdasarkan kriteria mutlak yang telah ditetapkan dapat dilihat pada Tabel 1.

Tabel 1. Konversi Nilai Kepuasan Penumpang $(Y)$

\begin{tabular}{ccccc}
\hline No & Interval & Frekuensi & Persentase & Kriteria \\
\hline 1. & $14-15$ & 64 & $64 \%$ & Sangat Puas \\
2. & $12-13$ & 31 & $31 \%$ & Puas \\
3. & $10-11$ & 2 & $2 \%$ & Cukup \\
4. & $8-9$ & 2 & $2 \%$ & Tidak Puas \\
5. & $<8$ & 1 & $1 \%$ & Sangat Tidak Puas \\
\multicolumn{2}{c}{ Jumlah } & 100 & $100 \%$ & \\
\hline
\end{tabular}

Berdasarkan Tabel 1, banyaknya responden yang mempersepsikan kepuasan penumpang pada kualifikasi atau kategori sangat puas sebanyak 64 responden (64\%), kualifikasi atau kategori puas sebanyak 31 responden (31\%), kualifikasi atau kategori cukup sebanyak 2 responden (2\%), sisanya pada kualifikasi atau kategori tidak puas sebanyak 2 responden (2\%), dan kualifikasi atau kategori sangat tidak puas sebanyak 1 responden (1\%). Hal ini dapat disimpulkan kepuasan penumpang pada jasa angkutan umum di Kota Ambon selama masa pandemi Covid-19 secara umum memiliki kualifikasi sangat puas.

\section{b) Variabel Mutu Pelayanan $\left(X_{1}\right)$}

Analisa data variabel mutu pelayanan mempunyai 3 butir pertanyaan pada instrumen serta memiliki 5 pilihan (sangat puas, puas, cukup, tidak puas, dan sangat tidak 
puas). Adapun secara rinci deskripsi mutu pelayanan berdasarkan kriteria mutlak yang telah ditetapkan dapat dilihat pada Tabel 2.

Tabel 2. Konversi Nilai Mutu Pelayanan $\left(X_{1}\right)$

\begin{tabular}{ccccc}
\hline No & Interval & Frekuensi & Persentase & Kriteria \\
\hline 1. & $14-15$ & 25 & $25 \%$ & Sangat Puas \\
2. & $12-13$ & 58 & $58 \%$ & Puas \\
3. & $10-11$ & 13 & $13 \%$ & Cukup \\
4. & $8-9$ & 4 & $4 \%$ & Tidak Puas \\
5. & $<8$ & 0 & $0 \%$ & Sangat Tidak Puas \\
\multicolumn{2}{c}{ Jumlah } & 100 & $100 \%$ & \\
\hline
\end{tabular}

Berdasarkan Tabel 2, banyaknya responden yang mempersepsikan mutu pelayanan pada kualifikasi atau kategori sangat puas sebanyak 25 responden (25\%), kualifikasi atau kategori puas sebanyak 58 responden (58\%), kualifikasi atau kategori cukup sebanyak 13 responden (13\%), sisanya pada kualifikasi atau kategori tidak puas sebanyak 4 responden (4\%), dan kualifikasi atau kategori sangat tidak puas sebanyak 0 responden $(0 \%)$. Hal ini dapat disimpulkan mutu pelayanan penumpang pada jasa angkutan umum di Kota Ambon selama masa pandemi Covid-19 secara umum memiliki kualifikasi puas.

\section{c) Variabel Harga $\left(X_{2}\right)$}

Analisis data variabel harga mempunyai 3 butir pertanyaan pada instrumen serta memiliki 5 pilihan (sangat terjangkau, terjangkau, cukup, tidak terjangkau, dan sangat tidak terjangkau). Adapun secara rinci deskripsi angkutan umum berdasarkan kriteria mutlak yang telah ditetapkan dapat dilihat pada Tabel 3.

Tabel 3. Konversi Nilai Harga $\left(X_{2}\right)$

\begin{tabular}{ccccc}
\hline No & Interval & Frekuensi & Persentase & Kriteria \\
\hline 1. & $14-15$ & 42 & $42 \%$ & Sangat Terjangkau \\
2. & $12-13$ & 47 & $47 \%$ & Terjangkau \\
3. & $10-11$ & 7 & $7 \%$ & Cukup \\
4. & $8-9$ & 4 & $4 \%$ & Tidak Terjangkau \\
5. & $<8$ & 0 & $0 \%$ & Sangat Tidak Terjangkau \\
\multicolumn{2}{c}{ Jumlah } & 100 & $100 \%$ & \\
\hline
\end{tabular}

Berdasarkan Tabel 3, banyaknya responden yang mempersepsikan harga angkutan umum pada kualifikasi atau kategori sangat terjangkau sebanyak 42 responden (42\%), kualifikasi atau kategori terjangkau sebanyak 47 responden (47\%), kualifikasi 
atau kategori cukup sebanyak 7 responden (7\%), sisanya pada kualifikasi atau kategori tidak terjangkau sebanyak 4 responden (4\%), dan kualifikasi atau kategori sangat tidak terjangkau sebanyak 0 responden $(0 \%)$. Hal ini dapat disimpulkan harga pada jasa angkutan umum di Kota Ambon selama masa pandemi Covid-19 secara umum memiliki kualifikasi terjangkau.

\section{d) Variabel Keselamatan Penumpang $\left(X_{3}\right)$}

Analisis data variabel keselamatan penumpang mempunyai 3 butir pertanyaan pada instrumen serta memiliki 5 pilihan (sangat puas, puas, cukup, tidak puas, dan sangat tidak puas). Adapun secara rinci deskripsi keselamatan penumpang berdasarkan kriteria mutlak yang telah ditetapkan dapat dilihat pada Tabel 4 .

Tabel 4. Konversi Nilai Keselamatan Penumpang $\left(X_{3}\right)$

\begin{tabular}{ccccc}
\hline No & Interval & Frekuensi & Persentase & Kriteria \\
\hline 1. & $14-15$ & 76 & $76 \%$ & Sangat Puas \\
2. & $12-13$ & 22 & $22 \%$ & Puas \\
3. & $10-11$ & 0 & $0 \%$ & Cukup \\
4. & $8-9$ & 1 & $1 \%$ & Tidak Puas \\
5. & $<8$ & 1 & $1 \%$ & Sangat Tidak Puas \\
\multicolumn{2}{c}{ Jumlah } & 100 & $100 \%$ & \\
\hline
\end{tabular}

Banyaknya responden yang mempersepsikan keselamatan penumpang pada kualifikasi atau kategori sangat puas sebanyak 76 responden (76\%), kualifikasi atau kategori puas sebanyak 22 responden (22\%), kualifikasi atau kategori cukup sebanyak 0 responden $(0 \%)$, sisanya pada kualifikasi atau kategori tidak puas sebanyak 1 responden (1\%), dan kualifikasi atau kategori sangat tidak puas sebanyak 1 responden (1\%). Hal ini dapat disimpulkan keselamatan penumpang pada jasa angkutan umum di Kota Ambon selama masa pandemi Covid-19 secara umum memiliki kualifikasi sangat puas.

\subsection{Model SEM}

\section{a) Spesifikasi Model}

Pada tahap ini dibentuk suatu model yang menggambarkan hubungan antara variabel laten yang satu dengan variabel laten yang lain, maupun variabel laten dengan variabel indikatornya yang didasarkan pada teori yang berlaku.

Penggabungan seluruh komponen SEM menjadi suatu model lengkap biasa disebut full dan hybrid model yang digambarkan dalam suatu diagram jalur (path diagram) yang ditunjukkan pada Gambar 1 untuk mempermudah melihat hubunganhubungan yang ingin diuji. 


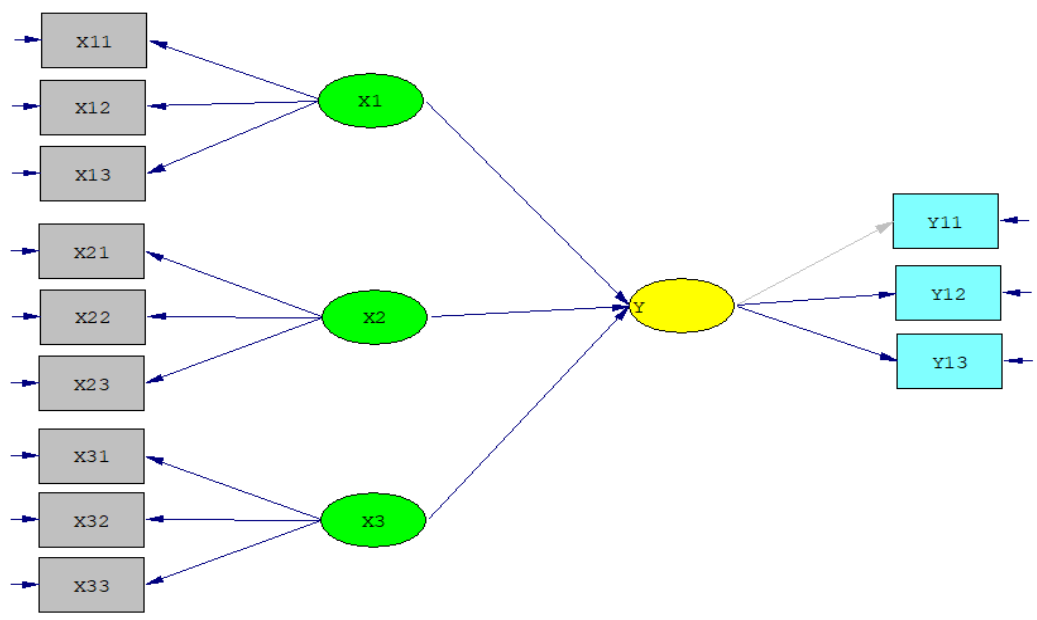

Gambar 1. Path Diagram Hybrid Model

\section{b) Identifikasi Model}

Setelah dilakukan spesifikasi model, langkah selanjutnya adalah mengidentifikasi model tersebut. Pada analisis SEM diharapkan memperoleh model yang over-identified $(d f>0)$ dan dihindari model yang under-identified $(d f<0)$. Pada penelitian ini diperoleh nilai degree of freedom yaitu 32 sehingga model tersebut adalah over-identified.

\section{c) Estimasi Model}

Setelah dilakukan spesifikasi dan identifikasi model maka tahap selanjutnya yang dilakukan adalah mengestimasi model. Pada penelitian ini, data tidak berdistribusi normal multivariat sehingga model diestimasi menggunakan metode maximum likelihood dengan memperhatikan standar error dan goodness of fit akibat ketidaknormalan data tersebut. Berdasarkan penelitian ini, hasil estimasi dapat dilihat pada Gambar 2.

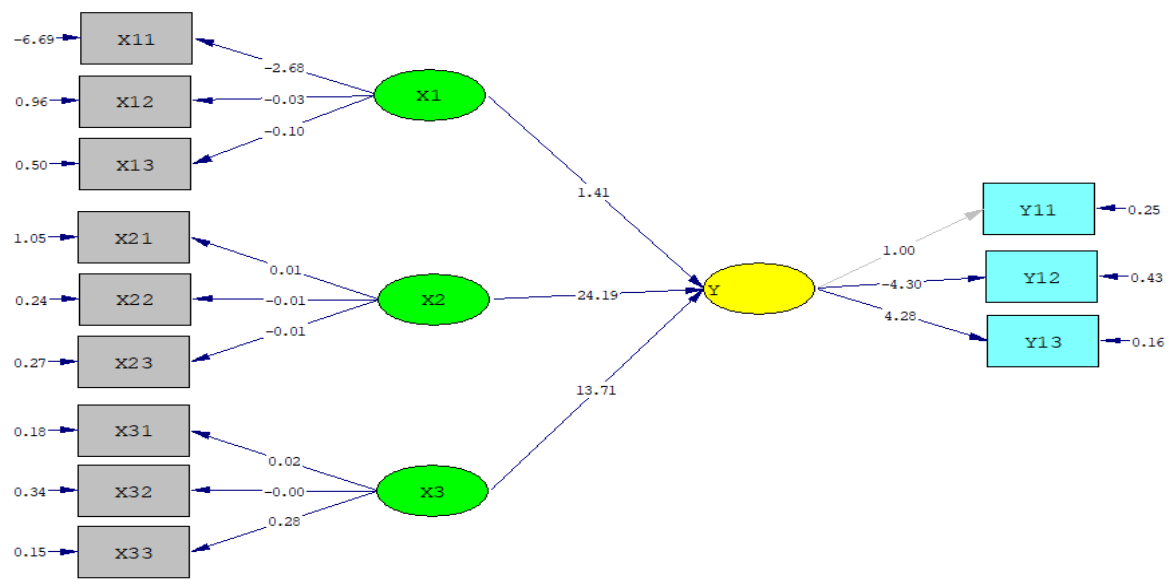

Chi-Square $=465.93, \mathrm{df}=48, \mathrm{P}-\mathrm{value}=0.00000, \quad$ RMSEA $=0.295$

Gambar 2. Diagram Hasil Estimasi Model 


\section{d) Uji Kecocokan Model dan Respesifikasi}

Dalam tahap ini tingkat kecocokan diperiksa antara data dengan model dan dilakukan pengujian secara bertahap. Tahap pertama pengujian dilakukan terhadap model pengukuran untuk mencapai uji kelayakan model yang baik, kemudian tahap kedua dilakukan pengujian secara struktural untuk setiap variabel.

\section{Uji Kecocokan dan Respesifikasi Model Pengukuran}

Pada tahap ini akan dilakukan validasi untuk mengetahui kesesuaian antara variabel laten dan variabel indikator yang ingin diukur. Pertama dilakukan uji validitas terhadap model pengukuran dengan memperhatikan muatan faktor standarnya (standardized loading factors) $\geq 0,50$. Standardized loading factors dari model pengukuran dapat dilihat pada Gambar 3.

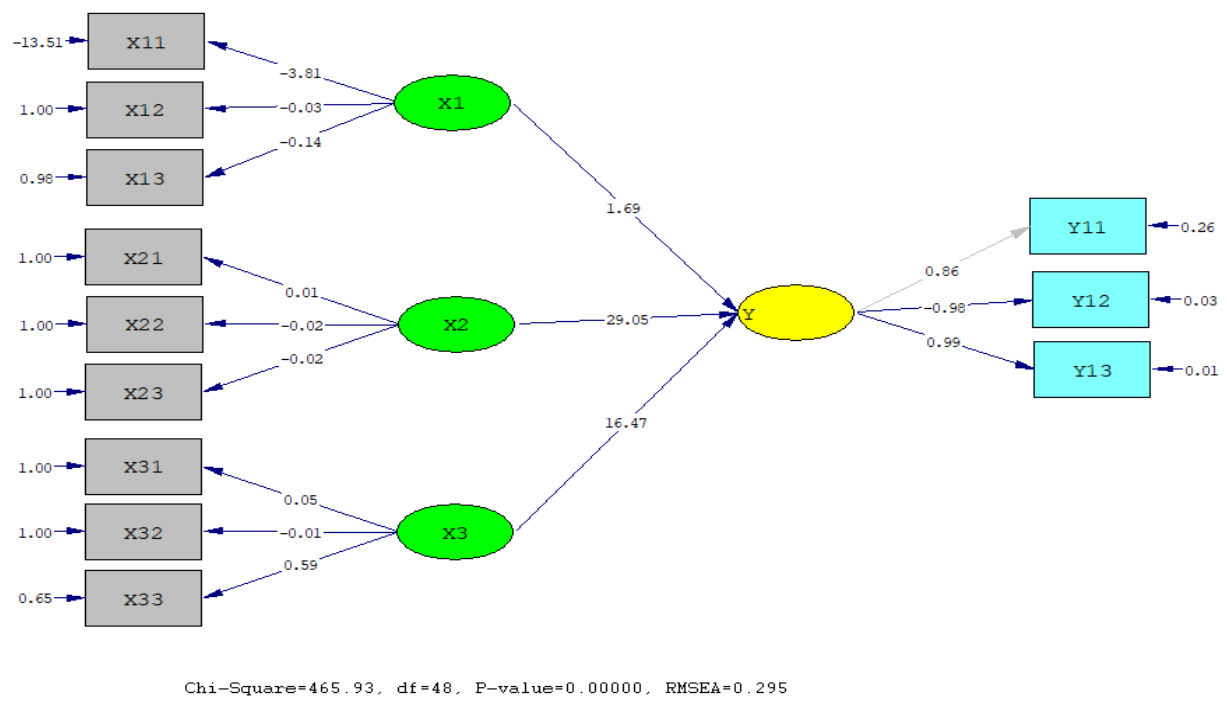

\section{Gambar 3. Hasil Standardized Loading Factors}

Gambar 3 menunjukkan bahwa seluruh muatan faktor standarnya (standardized loading factors) lebih besar sama dengan 0,50, $p$-value $\geq 0,50$, dan nilai Chi-Square semakin kecil semakin baik. Dapat dikatakan bahwa keseluruhan model pengukuran dengan semua nilai variabel teramati valid.

\section{Uji Kecocokan dan Respesifikasi Model Struktural}

Pada tahap ini telah diperoleh kecocokan model yang baik, sehingga diperoleh indikator-indikator dari variabel laten, yaitu

1) Indikator dari variabel laten mutu pelayanan adalah $X_{11}, X_{12}$, dan $X_{13}$

2) Indikator dari variabel laten harga adalah $X_{21}, X_{22}$, dan $X_{23}$ 
3) Indikator dari variabel laten keselamatan adalah $X_{31}, X_{32}$, dan $X_{33}$

4) Indikator dari variabel laten kepuasan penumpang adalah $Y_{11}, Y_{12}$, dan $Y_{13}$

\section{Uji Kecocokan Keseluruhan Model}

Hasil uji kecocokan keseluruhan model ditunjukkan pada Tabel 5. Hooper et al. [9], menilai ukuran kecocokan model dengan melihat nilai chi-square, RMSEA, CFI, dan RMSR. Tabel 5 menunjukkan bahwa model sudah sesuai sehingga dapat digunakan sebagai dasar analisis terhadap permasalahan penelitian ini.

Tabel 5. Uji Kecocokan Keseluruhan Model

\begin{tabular}{|c|c|c|c|}
\hline GOF & $\begin{array}{c}\text { Tingkat Kecocokan yang Dapat } \\
\text { Diterima }\end{array}$ & Indeks Model & Keterangan \\
\hline $\begin{array}{l}\text { Chi- } \\
\text { Square }\end{array}$ & $\begin{array}{l}\text { Semakin kecil semakin baik ( } p \text {-value } \\
\geq 0,50 \text { ) }\end{array}$ & $12,023(p=1,00)$ & Baik \\
\hline $\mathrm{NCP}$ & Semakin kecil semakin baik & 0,22 & Baik \\
\hline GFI & $\begin{array}{l}\text { GFI } \geq 0,90 \text { good fit } \\
0,80 \leq G F I \leq 0,90 \text { marginal fit }\end{array}$ & 0,84 & Cukup \\
\hline RMSR & RMSR $\leq 0,50$ good fit & 2,55 & Baik \\
\hline RMSEA & RMSEA $\leq 0,50$ good fit & 0,02 & Baik \\
\hline ECVI & dengan ECVI saturated $=5,259$ & & Baik \\
\hline NNFI & $\begin{array}{l}\text { NNFI } \geq 0,90 \text { good fit } \\
0,80 \leq N N F I \leq 0,90 \text { marginal fit }\end{array}$ & 1,00 & Baik \\
\hline NFI & $\begin{array}{l}\text { NFI } \geq 0,90 \text { good fit } \\
0,80 \leq N F I \leq 0,90 \text { marginal fit }\end{array}$ & 0,99 & Baik \\
\hline AGFI & $\begin{array}{l}\text { AGFI } \geq 0,90 \text { good fit } \\
0,80 \leq A G F I \leq 0,90 \text { marginal fit }\end{array}$ & 0,942 & Baik \\
\hline IFI & $\begin{array}{l}\mathrm{IFI} \geq 0,90 \text { good fit } \\
0,80 \leq I F I \leq 0,90 \text { marginal fit }\end{array}$ & 1,00 & Baik \\
\hline CFI & CFI $\geq 0,90$ good fit & 1,00 & Baik \\
\hline PGFI & Nilai lebih tinggi lebih baik & 0,518 & Cukup \\
\hline $\mathrm{CN}$ & $\mathrm{CFI} \geq 200$ baik & 216,656 & Baik \\
\hline
\end{tabular}

\section{Uji Kecocokan Model Pengukuran}

Setelah kecocokan model dan data keseluruhan adalah baik, maka langkah selanjutnya adalah menguji kecocokan model pengukuran dengan mengevaluasi setiap variabel laten dengan beberapa indikatornya. Gambar 4 adalah path diagram $t$ value.

Pada hasil estimasi $t$-value terdapat variabel yang tidak memiliki lintasan yaitu variabel KP ke $Y_{1}$. Hal ini dikarenakan variabel tersebut telah ditetapkan menjadi variance reference yang berarti variabel indikator tersebut secara nyata 
berhubungan dengan variabel latennya. Berdasarkan output analisis data, diperoleh hasil persamaan struktural yang ditunjukkan pada Tabel 6 .

Dari hasil penelitian diperoleh persamaan struktural

$$
K P=0,545 X_{1}+1,648 X_{2}+4,721 X_{3}
$$

Tabel 6 menunjukkan bahwa nilai $R^{2}$ sebesar 78,1\%, artinya variasi kepuasan penumpang (KP) yang dapat dijelaskan oleh mutu pelayanan $\left(X_{1}\right)$ dan harga $\left(X_{2}\right)$ serta keselamatan $\left(X_{3}\right)$ sebesar 78,1 persen.

Tabel 6. Hasil Analisis Persamaan Struktural

\begin{tabular}{ccccc}
\hline Variabel Laten Eksogen & Standardized Coeficient & $t$-value & Ket & $R^{2}$ \\
\hline$X_{1}$ & 0,545 & 14,06 & Signifikan & \\
$X_{2}$ & 1,648 & 241,88 & Signifikan & 0,781 \\
$X_{3}$ & 4,721 & 137,10 & Signifikan & \\
\hline
\end{tabular}

\section{e) Hipotesis Penelitian}

Hipotesis dalam penelitian ini dapat dilihat pada Tabel 7. Berdasarkan hasil yang diperoleh pada Gambar 4, diperoleh nilai t-value untuk variabel laten mutu pelayanan yaitu sebesar 14,06 (>1,96). Hal ini dapat disimpulkan bahwa variabel laten mutu pelayanan (MP) mempunyai pengaruh terhadap kepuasan penumpang. Variabel laten harga angkutan umum (H) sebesar 241,88 (>1,96). Hal ini dapat disimpulkan bahwa variabel laten harga angkutan umum mempunyai pengaruh terhadap kepuasan penumpang. Nilai untuk variabel laten keselamatan (K) mempunyai nilai sebesar 137,10 $(>1,96)$. Hal ini dapat disimpulkan bahwa variabel laten keselamatan penumpang mempunyai pengaruh terhadap kepuasan penumpang angkutan umum di Kota Ambon.

Tabel 7. Hipotesis Penelitian

\begin{tabular}{ccl}
\hline $\begin{array}{c}\text { Hipotesis } \\
\text { Pertama }\end{array}$ & $H_{0}$ & $\begin{array}{l}\text { Variabel mutu pelayanan tidak mempunyai pengaruh terhadap } \\
\text { kepuasan pelanggan. }\end{array}$ \\
\hline $\begin{array}{c}\text { Variabel mutu pelayanan mempunyai pengaruh terhadap kepuasan } \\
\text { pelanggan. }\end{array}$ & $\begin{array}{l}\text { Variabel harga tidak mempunyai pengaruh terhadap kepuasan } \\
\text { pelanggan. }\end{array}$ \\
\hline Kedua & $H_{1}$ & $\begin{array}{l}\text { Variabel harga mempunyai pengaruh terhadap kepuasan pelanggan. } \\
\text { Hipotesis } \\
\text { Ketiga }\end{array}$ \\
$H_{0}$ & $\begin{array}{l}\text { Variabel keselamatan tidak mempunyai pengaruh terhadap } \\
\text { kepuasan pelanggan. }\end{array}$ \\
$\begin{array}{l}\text { Variabel keselamatan mempunyai pengaruh terhadap kepuasan } \\
\text { pelanggan. }\end{array}$ \\
\hline
\end{tabular}




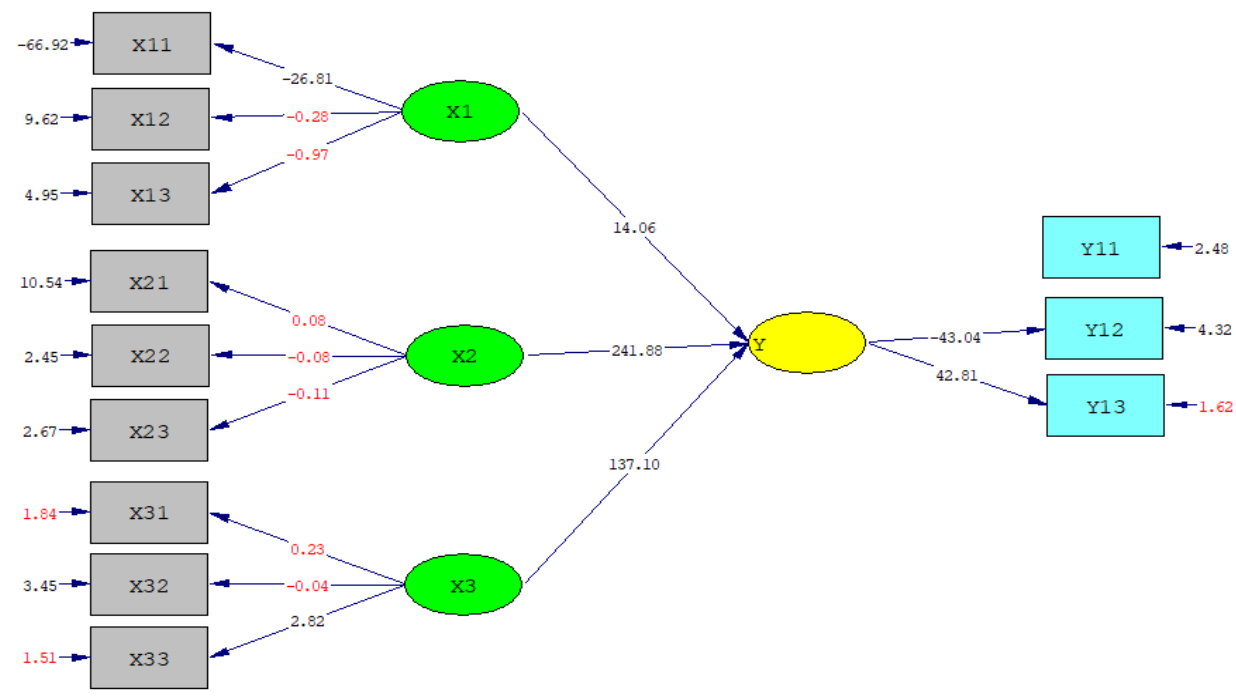

Chi-Square $=465.93, d f=48, P-$ value $=0.00000, \quad$ RMSEA $=0.295$

Gambar 4. Path Diagram t-Value

\section{Kesimpulan}

Berdasarkan hasil analisis dan pembahasan pada bab sebelumnya, maka penelitian ini dapat disimpulkan bahwa tingkat kepuasan penumpang jasa angkutan umum di Kota Ambon selama masa pandemi Covid-19 secara umum memiliki kualifikasi sangat tinggi. Variabel mutu pelayanan penumpang pada jasa angkutan umum di Kota Ambon selama masa pandemi Covid-19 secara umum memiliki kualifikasi tinggi. Variabel harga pada jasa angkutan umum di Kota Ambon selama masa pandemi Covid19 secara umum memiliki kualifikasi tinggi. Selanjutnya variabel keselamatan penumpang selama masa pandemi Covid-19 di Kota Ambon secara umum memiliki kualifikasi sangat tinggi.

Variabel laten mutu pelayanan (MP) mempunyai pengaruh yang signifikan terhadap kepuasan penumpang (KP) karena nilai $t$-value dari kepuasan penumpang yaitu sebesar 14,06 atau lebih besar dari 1,96 (untuk taraf nyata 5\%). Variabel laten harga angkutan umum $(\mathrm{H})$ mempunyai pengaruh yang signifikan terhadap kepuasan penumpang, karena nilai $t$-value yaitu sebesar 241,88 atau lebih besar dari 1,96 (untuk taraf nyata 5\%). Untuk variabel keselamatan penumpang (KP) mempunyai pengaruh yang signifikan terhadap kepuasan penumpang, karena nilai $t$-value yaitu sebesar 137,10 atau lebih besar dari 1,96 (untuk taraf nyata 5\%). Besar pengaruh variabel mutu pelayanan, harga dan keselamatan terhadap kepuasan penumpang yaitu sebesar $78,1 \%$, sisanya $21,9 \%$ dipengaruhi oleh variabel lain di luar penelitian. 


\section{Daftar Pustaka}

[1] Pradana, A. A. dan Casman, C. Pengaruh Kebijakan Social Distancing pada Wabah COVID-19 terhadap Kelompok Rentan di Indonesia. Jurnal Kebijakan Kesehatan Indonesia (JKKI). 9(2): 61-67. 2020.

[2] Kresna, A. dan Ahyar, J. Pengaruh Physical Distancing dan Social Distancing Terhadap Kesehatan dalam Pendekatan Linguistik. Jurnal Syntax Transformation. 1(4): 14-19. 2020.

[3] Rahmatullah, I. Jaminan Hak Kesehatan Pekerja Work From Office Selama Masa PSBB Covid-19. 'ADALAH, 4(1). 2020.

[4] Hartanto, H. dan Tajsgoani, N. Dualisme Pengaturan Ojek Online Angkut Penumpang dalam Pembatasan Sosial Berskala Besar (PSBB) di Jakarta. Al-'Adl, 13(2): 250-264. 2020.

[5] Anuraga, G. dan Otok, B. W. Pemodelan Kemiskinan di Jawa Timur dengan Structural Equation Modeling-Partial Least Square. Jurnal Statistika Universitas Muhammadiyah Semarang. 1(2). 2013.

[6] Singer, H. SEM Modeling with Singular Moment Matrices Part II: ML-Estimation of Sampled Stochastic Differential Equations. The Journal of Mathematical Sociology. 36(1): 22-43. 2012.

[7] Aulele, S. N., Hiariey, A. H., Lesnussa, Y. A., dan Matdoan, M. Y. Analisis Indeks Kepuasan Mahasiswa Jurusan Matematika FMIPA Unpatti Terhadap Operator simPATI Menggunakan Structural Equation Modeling. Sainmatika: Jurnal Ilmiah Matematika dan Ilmu Pengetahuan Alam. 15(1): 1-7. 2018.

[8] Hair Jr, J. F., Sarstedt, M., Hopkins, L., and Kuppelwieser, V. G. Partial Least Squares Structural Equation Modeling (PLS-SEM). European business review. 2014.

[9] Hooper, D., Coughlan, J., and Mullen, M. Structural Equation Modeling: Guidelines for determining Model Fit. The Electronic Journal of Business Research. 6(1): 354-373. 2008. 